DOI: 10.20472/IAC.2017.034.011

\author{
ANIL ÇAMYAMAÇ \\ CYPRUS SCIENCE UNIVERSITY FACULTY OF LAW, Turkey
}

\title{
A BRIEF ASSESSMENT ABOUT THE LEGAL STATUS OF VATICAN
}

\begin{abstract}
:
For a long time in history, Papal State was one of the most powerful state in all over Europe with the Pope as a head of state. But, the situation had changed after it lost its territory to Italy, which, as a consequnce, developed the problem of the status of Vatican under the principles of international law. At the time it continued to act as if it was a state, and some states promoted the very idea. This complex situation somehow eased by the conclusion of 1929 Lateran Treaty with Italy, in which a small territory was given to it and recognized its sovereignty over it. But, the question of status, as it would appear, has remained stand-still. In this respect, some jurists in doctrine challenges the status of Vatican as a state and acknowledges it as a sui generis subject of international law, while some recognizes it as a state. Hence, in this brief assessment the question of the legal status of Vatican will be analyzed.
\end{abstract}

\section{Keywords:}

Vatican, Holy See, Lateran Treaty (1929), Subjects of International Law, Papal State

JEL Classification: K33, F50 